\title{
Hubungan Pengetahuan dan Sikap Dengan Tindakan Pencegahan Gangguan Fungsional Pernapasan pada Pekerja di UMKM Mebel
}

\author{
Relationship of Knowledge and Attitudes With Respiratory Functional \\ Disorders Prevention Actions in UMKM Furniture Workers
}

\author{
Cornelis Novianus $^{(1)}$, Awaluddin Hidayat Ramli Inaku ${ }^{(1)}$, Haris Muzakir ${ }^{(1)}$ \\ ${ }^{(1)}$ Program Studi Kesehatan Masyarakat, Fakultas Ilmu-Ilmu Kesehatan \\ Universitas Muhammadiyah Prof. DR. Hamka Jakarta, Indonesia
Korespondensi Penulis: Cornelis Novianus, Program Studi Kesehatan Masyarakat, Fakultas Ilmu-Ilmu Kesehatan, Universitas Muhammadiyah Prof. DR. Hamka Email: Cornelius.anovian@uhamka.ac.id

\begin{abstract}
ABSTRAK
Industri mebel khususnya pada tahapan produksi mebel mempunyai risiko terhadap kesehatan pekerja yang cukup besar berupa partikulat debu kayu dapat menyebabkan gangguan fungsional saluran pernapasan bagian atas dan bawah. Tujuan penelitian ini adalah mengetahui hubungan pengetahuan dan sikap dengan tindakan pencegahan gangguan fungsional pernapasan pada pekerja UMKM Mebel di Jakarta Timur. Penelitian ini merupakan penelitian analitik dengan pendekatan cross sectional, alat pengumpulan data penelitian menggunakan lembar kuesioner. Pengambilan sampel dengan teknik proposional random sampling berdasarkan wilayah Kecamatan yang ada di Jakarta Timur dengan jumlah sampel yang didapat 107 pekerja pada UMKM mebel. Analisis data dilakukan secara univariat dan bivariat dengan uji chi square. Berdasarkan hasil penelitian didapatkan variabel yang berhubungan dengan tindakan pencegahan gangguan fungsional pernapasan yaitu pengetahuan dengan $\mathrm{p}$ value 0,014 , sikap dengan $\mathrm{p}$ value 0,019 , pendidikan dengan $\mathrm{p}$ value 0,030 . Sedangkan variabel yang tidak berhubungan dengan tindakan pencegahan gangguan fungsional pernapasan yaitu umur dengan $p$ value 0,220 dan masa kerja dengan $\mathrm{p}$ value 0,999 . Kesimpulan penelitian ini sebagian besar pekerja UMKM mebel dari segi pengetahuan, sikap, pendidikan dan tindakannya dalam pencegahan gangguan fungsional pernapasan sudah cukup baik. Rekomendasi untuk para pekerja mebel hendaknya dapat meningkatkan tindakan pencegahan gangguan fungsional pernapasan melalui memakai masker partikel secara disiplin, memasang yang sesuai panduan dan menggunakan masker partikel yang kondisinya layak pakai.
\end{abstract}

Kata Kunci: pengetahuan, sikap, pekerja mebel, tindakan pencegahan gangguan pernapasan.

\begin{abstract}
The furniture industry especially at the furniture production stage has a significant risk to the health of workers in the form of wood dust which is a particulate can cause functional disorders of the upper and lower respiratory tract. Purpose this study was to determine the knowledge and attitudes relationship towards respiratory functional disorders prevention actions on UMKM furniture workers in East Jakarta. This research is a descriptive analytic study with a cross sectional approach, a research data collection tool using a questionnaire. Sampling using proportional random sampling techniques based on sub-districts in East Jakarta with the number of samples obtained by 107 UMKM furniture workers. Data analysis was performed univariate and bivariate with chi square test. Based on the results of the study, it was found that the variables related to respiratory functional disorders prevention action were knowledge with $p$ value 0.014 , attitudes with $p$ value 0.019 , education with a $p$ value of 0.030 . While variables not related to respiratory functional disorders prevention action are age with $p$ value 0,220 and years of service with $p$ value 0,999. The conclusion of this study most of the furniture UMKM furniture workers in terms of knowledge, attitudes, education and actions in preventing respiratory functional disorders action are good enough. Recommendations for furniture workers should be able to improve the prevention of respiratory functional disorders action by using disciplined particle masks, installing according to guidelines and using particle masks in suitable condition.
\end{abstract}

Keywords: knowledge, attitude, UMKM furniture Workers, respiratory functional disorders prevention actions. 


\section{PENDAHULUAN}

Industri pengolahan kayu atau mebel merupakan salah satu sektor industri yang terus berkembang di Indonesia. Kondisi ini membuat peningkatan jumlah tenaga kerja, khususnya di sektor industri pengolahan mebel tersebut. Pada proses kerja di UMKM mebel tersebut melewati beberapa tahap proses, yaitu proses penggergajian, proses menyiapkan bahan baku, proses menyiapkan komponen, proses merakit, proses pembentukan, dan proses akhir berupa pengamplasan serta pengepakan (Depkes RI, 2020).

Debu kayu hasil kegiatan penggergajian dan penghalusan akan berterbangan di udara dan debu yang masuk ke dalam organ pernapasan manusia dapat menimbulkan gangguan pernapasan pada pekerja. Partikel debu yang terhirup dan tertahan di jaringan paru-paru dapat bertambah seiring dengan rutinnya paparan debu tersebut (Sekarwati, 2018).

Menurut Scott (2018), debu kayu merupakan partikulat yang dapat menyebabkan iritasi pada mata dan saluran pernapasan bagian atas dan bawah. Berdasarkan Peraturan Menteri Tenaga Kerja dan Transmigrasi nomor 13/Men/X/2011 mengenai nilai ambang batas (NAB) faktor fisika dan kimia di tempat kerja, NAB untuk debu kayu yang lunak sebesar 5 $\mathrm{mg} / \mathrm{m} 3$ dengan lama pemajanan debu tidak melebihi dari 8 jam perhari atau 40 jam dalam seminggu (Kementrian Tenaga Kerja RI, 2011). Dari data WHO sekitar 30\% sampai 50\% di antara semua penyakit akibat kerja adalah penyakit pneumokoniosis. Selain itu, dideteksi bahwa 40.000 kasus baru pneumokoniosis yang diakibatkan paparan debu di tempat kerja terjadi di setiap negara tiap tahunnya (World Health Organization, 2017).

Bentuk dari pencegahan pada pekerja terhadap penyakit akibat kerja adalah penggunaan alat pelindung diri atau APD pada saat melakukan pekerjaan. Alat pelindung diri adalah perangkat yang digunakan oleh pekerja untuk melindungi dirinya dari potensi bahaya maupun penyakit akibat kerja yang potensial dapat terjadi di tempat kerja. Meskipun penggunaan alat pelindung diri berada pada tingkat pencegahan paling akhir dalam teori hirarki pengendalian, namun penerapan APD pada pekerja ini sangatlah dianjurkan (Tarwaka, 2015). Pemakaian APD oleh pekerja seringkali diabaikan. Kondisi tersebut dipengaruhi oleh berbagai faktor, seperti pengetahuan dan sikap pekerja. Hasil penelitian Puji (2017) menyatakan bahwa pekerja yang patuh menggunakan APD sebagian besar pengetahuannya baik $(77,3 \%)$ dan hasil uji statistik menunjukkan bahwa ada hubungan bermakna antara pengetahuan dengan kepatuhan penggunaan APD ( $\mathrm{p}$ value 0,008), serta sikap pekerja juga berpengaruh terhadap kepatuhan penggunaan APD (p value 0,017 ).

Di Jakarta Timur, terdapat beberapa usaha mebel yang dikelola oleh masyarakat setempat berupa UMKM mebel tersebut cenderung kurang diperhatikan dari segi kesehatan pekerjanya. Hasil observasi pendahuluan dengan melakukan survei dan wawancara langsung kepada pekerjanya, diperoleh informasi bahwa hanya sebagian kecil pekerja yang menggunakan alat pelindung diri seperti masker saat bekerja, alasan mereka tidak menggunakan APD antara lain adalah karena kurang paham tentang manfaat APD, yang bagi mereka cenderung membuat repot dalam pemakaiannya dan membatasi ruang gerak.

Berdasarkan permasalah penelitian tersebut ingin mengetahui hubungan pengetahuan dan sikap, umur, masa kerja dan pendidika pekerja terhadap tindakan pencegahan gangguan fungsional pernapasan pada pekerja di UMKM Mebel di Jakarta Timur.

\section{SUB YEK DAN METODE}

Penelitian ini merupakan penelitian analitik dengan pendekatan Cross Sectional. Penelitian ini bertujuan untuk melihat hubungan variabel independen yaitu karakteristik pekerja (umur dan pendidikan), pengetahuan, sikap, dan variabel dependen yaitu tindakan pencegahan gangguan fungsional pernapasan.

Populasi penelitian adalah pekerja pada UMKM mebel di wilayah Jakarta Timur, karena terbatasanya data konkrit jumlah seluruh pekerja pada UMKM mebel di wilayah Jakarta Timur yang merupakan pekerja informal, sehingga dalam menentukan sampel penelitian ini menggunakan rumus besar sampel dengan tidak mempertimbangkan populasi (Sastroasmoro, 2014). Berdasarkan hasil dari rumus besar sampel 96,04 dibulatkan menjadi 97 dan ditambah $10 \%$ untuk mencegah sampel drop out sehingga jumlah sampel penelitian ini sebanyak 107 pekerja pada UMKM Mebel di wilayah Jakarta Timur. Pengambilan sampel dengan teknik proposional random sampling berdasarkan wilayah Kecamatan dengan jumlah sampel 107 pekerja pada UMKM mebel dibagi rata dengan 10 Kecamatan yang ada di wilayah Jakarta Timur sebanyak 10 Kecamatan, 
didapatkan hasil 1 Kecamatan dengan 10-11 sampel pekerja pada UMKM mebel, untuk penentuan sampel di setiap Kecamatan menggunakan simpel random sampling.

Instrumen pengumpulan data
menggunakan lembar kuesioner yang terdiri dari variabel-variabel yang akan diteliti. Sebelum diberikan kepada sampel penelitian kuesioner di uji cobakan terlebih dahulu kepada bukan sampel tetapi memiliki karakteristik yang sama dengan sampel, setelah itu dilakukan uji validitas dan uji realibilitas, setelah valid dan reliabel kuesioner diberikan kepada sampel penelitian untuk diisi.

Analisis data dilakukan secara univariat dan bivariat. Analisis univariat mempunyai tujuan untuk mendapat gambaran distribusi variabel maupun responden yang diteliti. Analisis univariat dalam penelitian ini disajikan hanya menggunakan distribusi frekuensi dan persentase dari setiap variabel yang diteliti. Analisis bivariat yang dilakukan berupa tabulasi silang antar dua variabel, yaitu variabel dependen dengan independen. Analisis bivariat bertujuan melihat ada tidaknya hubungan antara variabel independen dan variabel dependen seperti yang tampak dalam kerangka konsep. Uji yang dipakai dalam penelitian ini adalah chi square.

\section{HASIL}

Hasil penelitian dengan menggunakan analisis univariat dan bivariat dapat dilihat dalam tabel berikut:

Tabel 1. Distribusi Frekuensi Tindakan Pencegahan Gangguan Fungsional Pernapasan, Pengetahuan, Sikap, Umur, Masa Kerja dan Pendidikan pada pekerja UMKM Mebel

\begin{tabular}{|c|c|c|c|c|}
\hline \multicolumn{2}{|l|}{ Variabel } & Kategori & $\mathrm{n}$ & $\%$ \\
\hline \multirow{2}{*}{\multicolumn{2}{|c|}{$\begin{array}{l}\text { Tindakan pencegahan gangguan } \\
\text { fungsional pernapasan }\end{array}$}} & Kurang baik & 44 & 41,1 \\
\hline & & Baik & 63 & 58,9 \\
\hline \multirow[t]{2}{*}{ Pengetahuan } & & Rendah & 29 & 27,1 \\
\hline & & Tinggi & 78 & 72,9 \\
\hline \multirow[t]{2}{*}{ Sikap } & & Negatif & 50 & 46,7 \\
\hline & & Positif & 57 & 53,3 \\
\hline \multirow[t]{2}{*}{ Umur } & & $<31$ tahun & 52 & 48,6 \\
\hline & & $\geq 31$ tahun & 55 & 51,4 \\
\hline \multirow[t]{2}{*}{ Masa Kerja } & & $<5$ tahun & 45 & 42,1 \\
\hline & & $\geq 5$ tahun & 62 & 57,9 \\
\hline \multirow[t]{2}{*}{ Pendidikan } & & Rendah & 66 & 61,7 \\
\hline & & Menengah & 41 & 38,3 \\
\hline
\end{tabular}

Tabel 2. Hasil analisis bivariat Hubungan Variabel Independen dengan Variabel Dependen

\begin{tabular}{|c|c|c|c|c|c|}
\hline \multirow[t]{3}{*}{ Variabel } & \multicolumn{4}{|c|}{ Tindakan Pencegahan Gangguan Fungsional Pernapasan } & \multirow{3}{*}{ P value } \\
\hline & \multicolumn{2}{|c|}{ Kurang Baik } & \multicolumn{2}{|c|}{ Baik } & \\
\hline & $\mathbf{n}$ & $\%$ & $\mathbf{n}$ & $\%$ & \\
\hline \multicolumn{6}{|l|}{ Pengetahuan } \\
\hline Rendah & 18 & 62,1 & 11 & 37,9 & \multirow{2}{*}{0,014} \\
\hline Tinggi & 26 & 33,3 & 52 & 66,7 & \\
\hline \multicolumn{6}{|l|}{ Sikap } \\
\hline Negatif & 27 & 54,0 & 23 & 46,0 & \multirow[t]{2}{*}{0,019} \\
\hline Positif & 17 & 29,8 & 40 & 70,2 & \\
\hline \multicolumn{6}{|l|}{ Umur } \\
\hline$<31$ tahun & 25 & 48,1 & 27 & 51,9 & \multirow[t]{2}{*}{0,220} \\
\hline$\geq 31$ tahun & 19 & 34,5 & 36 & 65,5 & \\
\hline \multicolumn{6}{|l|}{$\overline{\text { Masa Kerja }}$} \\
\hline$<5$ tahun & 18 & 40,0 & 27 & 60,0 & \multirow[t]{2}{*}{0,999} \\
\hline$\geq 5$ tahun & 26 & 41,9 & 36 & 58,1 & \\
\hline \multicolumn{6}{|l|}{ Pendidikan } \\
\hline Rendah & 33 & 50,0 & 33 & 50,0 & \multirow[t]{2}{*}{0,030} \\
\hline Menengah & 11 & 26,8 & 30 & 73,2 & \\
\hline
\end{tabular}


Berdasarkan tabel 1, terlihat bahwa sebagaian besar pekrja UMKM mebel menjawab melakukan tindakan yang baik dalam mencegahan gangguan pernapasan sebanyak 63 orang $(58,9 \%)$, sikap pekerja yang positif sebanyak 57 orang $(53,3 \%)$, umur pekerja $\geq 31$ tahun sebanyak 55 orang $(51,4 \%)$, masa kerja $\geq 5$ tahun sebanyak 62 orang $(57,8 \%)$, pendidikan pekerja yang rendah sebanyak 66 orang $(61,7 \%)$.

Berdasarkan tabel 2, terlihat bahwa variabel yang berhubungan bermakna dengan tindakan pencegahan gangguan fungsional pernapasan pada pekerja UMKM mebel adalah variabel pengetahuan dengan $\mathrm{p}$ value 0,014 , variabel sikap pekerja dengan $\mathrm{p}$ value 0,019 , variabel pendidikan dengan $\mathrm{p}$ value 0,030 . Sedangkan yang tidak berhubungan bermakna dengan tindakan pencegahan gangguan fungsional pernapasan pada pekerja UMKM mebel adalah variabel umur ( $p$ value 0,220 ) dan masa kerja ( $\mathrm{p}$ value 0,999$)$.

\section{DISKUSI}

\section{Tindakan Pencegahan Gangguan Fungsional Pernapasan pada pekerja UMKM Mebel}

Berdasarkan hasil penelitian ini, diketahui bahwa sebagian besar tindakan pencegahan gangguan fungsional pernapasan pada pekerja UMKM mebel adalah baik, yaitu sebanyak 63 orang $(58,9 \%)$. Tindakan pencegahan gangguan fungsional pernafasan pada pekerja UMKM mebel dalam penelitian ini adalah praktik yang dilakukan pekerja dalam menggunakan alat pelindung diri berupa masker pada saat bekerja. Hal tersebut penting dilakukan karena UMKM mebel tidak memiliki mesin yang cukup memadai untuk mengolah kayu sehingga harus diserut secara manual menggunakam tenaga manusia.

Menurut Depkes, terdapat lima tahap proses dalam menghasilkan produk mebel kayu, yaitu proses penggergajian, proses menyiapkan bahan baku, proses menyiapkan komponen, proses merakit, proses pembentukan, dan proses akhir berupa pengamplasan serta pengepakan. Pada lima tahapan tersebut dapat berisiko untuk terjadinya gangguan pernapasan karena debu dari proses produksi dapat terinhalasi ke dalam sistem pernapasan masuk ke dalam paru-paru para pekerja kayu (Depkes RI, 2002).
Penggunaan alat pelindung diri (APD) termasuk di dalamnya alat pelindung pernapasan seperti masker debu dan respirator sebagai pilihan terakhir dalam hirarki pengendalian bahaya di tempat kerja yang berdebu agar pekerja aman dari bahaya penyakit pernapasan dan kecelakaan akibat melakukan pekerjaannya (Hansari, 2003). Berdasarkan penelitian Fujianti (2015) menyatakan penggunaan alat pelindung diri memiliki pengaruh dalam mencegah terjadinya gangguan pernapasan pada pekerja mebel di Kota Jambi, hal ini juga didukung oleh penelitian Sekarwati (2018) yang menyatakan adanya hubungan penggunaan alat pelindung diri dengan gangguan pernapasan pada pekerja mebel di Kecamatan Sewon Santul.

Dalam penelitian ini, sebanyak $41,1 \%$ pekerja UMKM mebel tidak menggunakan masker sebagai bentuk tindakan pencegahan gangguan pernafasan. Kondisi tersebut dapat terjadi disebabkan oleh berbagai faktor, seperti pengetahuan dan sikap dari para pekerja tentang bahaya paparan kayu saat bekerja yang kurang baik. Kondisi ini juga didukung oleh latar belakang pendidikan yang rendah. Oleh sebab itu, tindakan pencegahan gangguan pernafasan yang dilakukan oleh pekerja UMKM mebel juga tidak dapat terwujud dengan optimal.

\section{Pengetahuan pekerja UMKM Mebel}

Berdasarkan hasil penelitian ini diketahui bahwa sebagian besar pekerja UMKM mebel memiliki pengetahuan yang tinggi, yaitu sebanyak 78 orang $(72,9 \%)$. Hasil analisis bivariat menunjukkan adanya hubungan yang bermakna antara pengetahuan dengan tindakan pencegahan gangguan fungsional pernapasan pada pekerja UMKM mebel dengan $\mathrm{p}$ value 0,014. Pengetahuan adalah hasil tahu dan ini terjadi setelah orang melakukan pengindraan terhadap suatu objek tertentu. Pengindraan terjadi melalui panca indra manusia, yakni indra penglihatan, pendengaran, penciuman, rasa dan raba. Sebagian besar pengetahuan manusia di peroleh melalui mata dan telinga (Notoatmodjo, 2012)

Teori perilaku dari Green mengemukakan bahwa pengetahuan merupakan domain yang sangat penting untuk terbentuknya tindakan seseorang. Dengan kata lain pengetahuan mempunyai pengaruh sebagai motivasi awal atau faktor predisposisi bagi seseorang dalam berperilaku (Notoatmodjo, 2012). 
Hasil penelitian ini didukung oleh penelitian yang dilakukan Muhajirin \& Teuku Tahlil (2016) menyatakan pengetahuan pekerja mebel kayu di wilayah Kota Banda Aceh sebagian besar berada pada kategori pengetahuan kurang dalam pencegahan risiko gangguan pernapasan. Berdasarkan penelitian oleh Putra \& Afriani (2018) menyatakan ada hubungan yang bermakna antara pengetahuan ( $p$ value 0,014 ) dengan gejala penyakit ISPA pada Pekerja, dan berdasarkan hasil penelitian Puji (2017) terhadap pekerja rekanan di PT. Indonesia Power UP Semarang, yang mengemukakan bahwa ada hubungan yang bermakna antara pengetahuan ( $\mathrm{p}$ value 0.008 ) dengan kepatuhan penggunaan alat pelindung diri dalam pencegahan penyakit, Sedangkan menurut penelitian Soongkhang \& Laohasiriwong (2015) menyatakan pengetahuan yang rendah sampai menengah memiliki faktor risiko yang tinggi untuk terjadinya penyakit saluran pernapasan pada pekerja manufaktur mebel di timur laut Thailand.

Pengetahuan sangat penting peranannya dalam mengubah perilaku seseorang. Pengetahuan sebagai salah satu modal dasar bagi seseorang untuk bertindak atau berperilaku. Melalui pengetahuan yang memadai, maka akan menjadi pertimbangan bagi seseorang untuk melakukan suatu tindakan. Jika para pekerja memiliki pengetahuan yang baik tentang bahaya paparan serpihan kayu mebel dan paham tentang cara mencegah gangguan pernafasan akibat paparan tersebut, maka otomatis para pekerja akan mau menggunakan masker saat bekerja (Sekarwati, 2018).

Berdasarkan penelitian terdahulu dan teori yang mendukung mengenai pengetahuan pada pekerja mebel pada hasil penelitian ini dapat disimpulkan pengetahuan pekerja yang baik dapat mempengaruhi tindakan pekerja dalam mencegah terjadinya gangguan fungsional pernapasan di UMKM mebel, sehingga perlu dilakukan pemberian promosi kesehatan kerja kepada pekerja di UMKM mebel oleh pengusahan mebel dan pemerintah dalam meningkatkan pengetahuan pekerja mengenai pencegahan gangguan fungsional pernapasan.

\section{Sikap Pekerja di UMKM Mebel}

Berdasarkan hasil penelitian, diketahui bahwa sebagian besar sikap pekerja UMKM mebel adalah positif, yaitu sebanyak 57 orang
$(53,3 \%)$. Hasil analisis bivariat menunjukkan adanya hubungan yang bermakna antara sikap dengan tindakan pencegahan gangguan fungsional pernapasan pada pekerja UMKM mebel dengan $p$ value $=0,019$.

Sikap adalah merupakan reaksi atau respon seseorang yang masih tertutup terhadap suatu stimulus atau objek Sikap termasuk dalam faktor predisposisi dalam pembentukan perilaku pada diri seseorang (Notoatmodjo, 2012).

Hasil penelitian ini sejalan dengan penelitian yang dilakukan oleh Puji (2017) bahwa ada hubungan antara sikap pekerja PT Indonesia Power UP Semarang dengan kepatuhan menggunakan alat pelindung diri sedangkan penelitian yang dilakukan oleh Saliha, Joseph, \& Kalesaran (2018) bahwa ada hubungan antara sikap ( $\mathrm{p}$ value 0,006 ) dengan kepatuhan dalam penggunaan APD dalam pencegahan penyakit. Berdasarkan hasil penelitian yang dilakukan oleh Repi, Josephus, \& A.J.M Rattu (2015) pada pekerja di PT Tropica Cocoprima Desa Lelema Kecamatan Tumpaan Kabupaten Minahasa Selatan bahwa ada hubungan antara pengetahuan ( $\mathrm{p}$ value $0,000)$ dengan tindakan penggunaan alat pelindung diri dalam mencegah penyakit pada pekerja.

Berdasarkan penelitian terdahulu dan teori yang mendukung mengenai sikap pada pekerja mebel pada hasil penelitian ini dapat disimpulkan sikap pekerja menggambarkan setuju maupun tidak setuju terhadap sesuatu hal atau obyek. Pekerja yang bersikap positif atau setuju terhadap pencegahan gangguan fungsional pernapasan, akan menjadi pendorong bagi pekerja untuk melakukan perilaku atau tindakan pencegahan tersebut, sehingga perlu dilakukan penyuluhan kesehatan kerja oleh Pemerintah dalam mendorong sikap pekerja menjadi positif mengenai pencegahan gangguan fungsional pernapasan.

\section{Umur Pekerja Pada UMKM Mebel}

Dalam penelitian ini umur tidak memiliki hubungan yang bermakna dengan tindakan pencegahan gangguan fungsional pernapasan pada pekerja UMKM mebel. Hal ini sejalan dengan penelitian yang dilakukan oleh Nurrizqi, Wardani, \& Gayatri (2019) pada pekerja di Kawasan indiustri mebel di Kota Pasuruan menyatakan ada hubungan antara umur pekerja mebel dengan keluhan ISPA, sedangkan menurut penelitian Puji (2017) pada 
pekerja rekanan PT $\mathrm{X}$ didapatkan tidak ada hubungan antara umur dengan kepatuhan penggunaan APD untuk pencegahan penyakit pada pekerja. Dan menurut penelitian yang dilakukan oleh Putri (2014) menyatakan tidak ada hubungan antara umur pekerja dengan kepatuhan penggunaan APD untuk mencegah penyakit pada para pekerja.

Tidak adanya hubungan yang bermakna antara umur dengan tindakan pencegahan gangguan fungsional pernapasan pada pekerja UMKM mebel dalam penelitian ini disebabkan oleh faktor lain yang pengaruhnya lebih besar terhadap tindakan pencegahan gangguan fungsional pernapasan yang dilakukan, seperti halnya pengetahuan, sikap, maupun pengawasan yang dilakukan. Walaupun pekerja berumur muda, namun pengetahuan dan sikap tentang tindakan pencegahan yang dimiliki pekerja membuatnya lebih patuh dalam melakukan tindakan pencegahan gangguan pernafasan sesuai dengan prosedur. Sehingga dalam memberikan promosi kesehatan kerja pengusaha mebel maupun Pemerintah harus mengikut sertakan semua umur pekerja mebel dari yang berumur muda sampai yang berumur tua.

\section{Masa Kerja pekerja UMKM Mebel}

Masa kerja adalah jangka waktu orang sudah bekerja dari pertama mulai masuk hingga sekarang masih bekerja. Masa kerja dapat diartikan sebagai sepenggal waktu yang agak lama dimana seorang tenaga kerja masuk dalam satu wilayah tempat usaha sampai batas waktu tertentu (Suma'mur, 2009).

Hasil penelitian ini menemukan bahwa masa kerja tidak memiliki hubungan yang bermakna dengan tindakan pencegahan gangguan fungsional pernapasan pada pekerja UMKM mebel. Hal tersebut menggambarkan bahwa tindakan pencegahan yang dilakukan oleh pekerja tidak ditentukan oleh masa kerjanya di tempat tersebut. Hal ini diperkuat oleh hasil penelitian yang dilakukan oleh Putri (2014) di unit produksi alumunium sulfat PT. Liku Telaga Gresik bahwa masa kerja ( $p$ value 1.000) tidak berhubungan dengan kepatuhan penggunaan APD. Sedangkan menurut penelitian Wardhani, Rachmawati, Rinawati, \& Seviana (2018) di PT Barata Indonesia menyatakan tidak ada hubungan masa kerja ( $p$ value 0,977 ) dengan gejala gangguan sistem pernapasan akibat paparan debu. Berdasarkan penelitian Suswanto pada pekerja di industri panic aluminium menyatakan tidak ada hubungan antara masa kerja (p value 1.000) dengan keluhan pernapasan pada pekerja.

Berdasarkan penelitian terdahulu dan teori yang mendukung mengenai masa kerja pada pekerja mebel pada hasil penelitian ini dapat disimpulkan masa kerja menggambarkan lamanya seorang bekerja di suatu tempat kerja, terkait dengan tindakan pencegahan gangguan pernapasan hal yang paling penting adalah pengetahuan dan sikap pekerja itu sendiri walaupun seorang pekerja sudah bekerja lama tidak menjamin pekerja tersebut melakukan tindakan pencegahan gangguan pernapasan di tempat kerjanya, sehingga dalam memberikan program-program Kesehatan kerja perlu dilibatkan semua pekerja dari pekerja yang baru berganbung sampai pekerja yang sudah lama bekerja di tempat mebel.

\section{Pendidikan pekerja UMKM Mebel}

Berdasarkan hasil penelitian, diketahui bahwa sebagian besar pekerja UMKM mebel berpendidikan rendah, yaitu sebanyak 66 orang $(61,7 \%)$. Dari hasil analisis bivariat menunjukkan adanya hubungan yang bermakna antara pendidikan dengan tindakan pencegahan gangguan fungsional pernapasan pada pekerja UMKM mebel dengan $\mathrm{p}$ value 0,030 .

Menurut Langeveld, yang dikutip oleh Normina (2017) pendidikan adalah setiap usaha, pengaruh, perlindungan, dan bantuan yang diberikan dan tertuju pada arah pendewasaan anak itu, atau membantu agar cukup cakap dalam melaksanakan tugas hidupnya sendiri. Pengaruh itu datangnya dari orang dewasa (atau yang diciptakan oleh orang dewasa seperti sekolah, buku, putaran hidup sehari-hari, dan sebagainya) yang ditujukan kepada orang yang belum dewasa.

Sehingga Pendidikan pada hakekatnya bertujuan mengubah tingkah laku sasaran pendidikan. Tingkah laku baru (hasil perubahan) itu dirumuskan dalam suatu tujuan pendidikan (educational objective), sehingga tujuan pendidikan pada dasarnya adalah suatu deskripsi dari pengetahuan, sikap, tindakan, penampilan dan sebagainya yang diharapkan akan dimiliki sasaran pendidikan pada periode tertentu (Notoatmodjo, 2012).

Diperkuat oleh penelitian yang dilakukan oleh Putri (2014) menunjukkan adanya hubungan antara pendidikan pekerja ( $\mathrm{p}$ value $0,005)$ dengan kepatuhan menggunakan alat pelindung diri untuk mencegah pekerja terpapar penyakit di unit produksi PT Liku Telaga Gresik. Sedangkan menurut penelitian Nurrizqi 
(2019) menyatakan ada hubungan antara pendidikan ( $\mathrm{p}$ value 0,037 ) dengan keluhan ISPA pada pekerja di kawasan industri mebel Kota Pasuruan.

Berdasarkan penelitian dari Sekarwati (2018) menyatakan pekerja yang memiliki tingkat pendidikan lebih tinggi cenderung untuk berperilaku lebih patuh dalam upaya pencegahan gangguan fungsional pernapasan dibandingkan dengan pekerja yang pendidikannya lebih rendah, dapat terjadi karena adanya perbedaan terkait dengan pemahaman dan pola pikir yang lebih baik khususnya pada mereka yang tingkat pendidikannya lebih tinggi

Berdasarkan penelitian terdahulu dan teori yang mendukung mengenai masa kerja pada pekerja mebel pada hasil penelitian ini dapat disimpulkan pendidikan dapat menjadi sumber pengetahuan bagi para pekerja untuk mengerti dan melakukan tindakan pencegahan gangguan fungsional pernapasan bagi dirinya. Hal ini dapat di simpulkan terjadi karena adanya perbedaan terkait dengan pemahaman dan pola pikir yang lebih baik khususnya pada mereka yang tingkat pendidikannya lebih tinggi. Sehingga dalam melakukan usaha penyuluhan dan pelatihan kesehatan kerja bagi pekerja di UMKM mebel perlu dilibatkan semua pekerja yang memiliki berbagai tingkatan pendidikan agar dapat mau bertindak mencegah gangguan fungsional pernapasan.

\section{KESIMPULAN}

Berdasarkan hasil penelitian, terlihat bahwa sebagian besar pekerja UMKM mebel mempunyai tindakan pencegahan gangguan fungsional pernapasan yang baik, pada pengetahuan dan sikap pekerja UMKM mebel hasilhya mempunyai pengetahuan dan sikap yang baik.

Hasil penelitian juga memperlihatkan bahwa variabel yang berhubungan dengan tindakan pencegahan gangguan fungsional pernapasan pada pekerja UMKM mebel adalah pengetahuan, sikap, dan pendidikan. Sedangkan yang tidak berhubungan bermakna dengan tindakan pencegahan gangguan fungsional pernapasan adalah umur dan masa kerja pekerja UMKM mebel.

Rekomendasi yang dapat diberikan dalam penelitian ini bagi pekerja mebel hendaknya dapat meningkatkan tindakan pencegahan gangguan fungsional pernapasan melalui memakai masker partikel secara displin, memasang masker partikel yang sesuai panduan dan menggunakan masker partikel yang kondisinya layak untuk pakai bekerja.

\section{UCAPAN TERIMA KASIH}

Ucapan terima kasih dihaturkan kepada Lembaga penelitian dan Pengembangan UHAMKA yang telah memberikan dukungan hibah penelitian sehingga terselesaikannya penelitian ini.

\section{DAFTAR PUSTAKA}

Depkes RI. (2002). Pedoman Teknis: Upaya kesehatan kerja bagi perajin (kulit,mebel, aki bekas,tahu,tempe dan batik). Retrieved from http://perpustakaan.kemkes.go.id/inlislite 3/uploaded_files/temporary/DigitalCollec tion/ZjU4YWIwNDg5Yzk4ZTJmYjUwZ mIyNmEyMjAyNWMyZGNhOWQ0Y2 $\mathrm{NlMg}==. p d f$

Fujianti, P., Hasyim, H., \& Sunarsih, E. (2015). Faktor-Faktor yang Mempengaruhi Timbulnya Keluhan Gangguan Pernapasan pada Pekerja Mebel Jati Berkah Kota Jambi. Jurnal Ilmu Kesehatan Masyarakat. https://doi.org/10.26553/jikm.2015.6.3.1 86-194

Green, L. W., \& Kreuter, M. W. (1992). CDCs planned approach to community health as an application of PRECEED and an inspiration for PROCEED. Journal of Health

Education. https://doi.org/10.1080/10556699.1992.1 0616277

Hansari. (2003). Penggunaan alat pelindung diri pada tenaga kerja, bunga Rampai Hiperkes dan Keselamatan Kerja. Semarang: UNDIP.

Muhajirin, \& Teuku Tahlil. (2016). Pengetahuan Pekerja Mebel kayu Tentang Resiko Gangguan Pernapasan di wilayah Kota Banda Aceh. I(1), 1-5. Retrieved from http://jim.unsyiah.ac.id/FKep/article/vie $\mathrm{w} / 1683$

Normina. (2017). Pendidikan dalam kebudayaan. Ittihad Jurnal Kopertais Wilayah XI Kalimantan, 15(28), 17-28.

Notoatmodjo, S. (2003). Pendidikan dan Perilaku Kesehatan. Jakarta: PT Rineka Cipta (2005). Metodologi Penelitian Kesehatan. https://doi.org/10.1007/BF00353361 
Nurrizqi, M. A., Wardani, H. E., \& Gayatri, R. W. (2019). Hubungan Riwayat Penyakit, APD , Pendidikan, Dan Umur Dengan Keluhan Ispa pada Pekerja di Kawasan Industri Mebel Kelurahan Bukir Kecamatan Gadingrejo Kota Pasuruan. 1(1), 39-50. Retrieved from http://journal2.um.ac.id/index.php/jfik/art icle/view/9987/4490

Peraturan Menteri Tenaga Kerja dan Transmigrasi. (2011). Nilai Ambang Batas Faktor fisika dan Faktor Kimia di Tempat Kerja. (13/Men/X).

Puji Dwi Andri. (2017). Faktor Faktor yang Berhubungan dengan Kepatuhan Penggunaan Alat Pelindung Diri pada Pekerja Rekanan (PT. X) DI PT Indonesia Power Up Semarang. Jurnal Kesehatan Masyarakat, 5 nomor 5.

Putra, B. H., \& Afriani, R. (2018). Kajian Hubungan Masa Kerja, Pengetahuan, Kebiasaan Merokok, Dan Penggunaan Masker Dengan Gejala Penyakit Ispa Pada Pekerja Pabrik Batu Bata Manggis Gantiang Bukittinggi. Human Care Journal, 2(2), 48-54. https://doi.org/10.32883/HCJ.V2I2.70

Putri, K. dyah sertiya, \& Denny, Y. (2014). Analisis Faktor Yang Berhubungan Dengan Kepatuhan Menggunakan Alat Pelindung Diri. Journal of Occupational Safety, Health and Environment.

Repi, A. A., Josephus, J., \& A.J.M Rattu. (2015). Hubungan Antara Pengetahuan dan Sikap dengan Tindakan Penggunaan Alat Pelindung Diri pada Tenaga Kerja di PT Tropica Cocoprima di Desa Lelema Kecamatan Tumpaan Kabupaten Minahasa Selatan. Retrieved from https://ejournal.unsrat.ac.id/index.php/ke smas/article/view/12681

Saliha, J., Joseph, W. B. S., \& Kalesaran, A. F. C. (2018). Hubungan Antara Pengetahuan dan Sikap dengan Kepatuhan Penggunaan Alat Pelindung Diri pada Pekerja PT. Hutama Karya Proyek Pembangunan Jalan Tol Manado-Bitung Tahun 2018. Jurnal KESMAS, 7(5), 1-8. Retrieved from

https://ejournal.unsrat.ac.id/index.php/ke smas/article/download/22425/22121

Sastroasmoro, S., \& Ismael, S. (2014). DasarDasar Metodologi Klinis Edisi Ke-4. In Dasar-Dasar Metodologi Peneltian Klinis.
https://doi.org/10.15294/UJPH.V2I1.303 4

Scott, R., \& Scott, R. (2018). Physical and Biological Hazards in the Workplace. In Basic Concepts of Industrial Hygiene. https://doi.org/10.1201/978131513807715

Sekarwati. (2018). Hubungan tingkat pengetahuan dan perilaku penggunaan alat pelindung diri (masker) dengan gangguan pernapasan di Industri Mebel di Wilayah Kecamatan Sewon Bantul. MIKKI.

Soongkhang, I., \& Laohasiriwong, W. (2015). Respiratory tract problems among wood furniture manufacturing factory workers in the Northeast of Thailand. Kathmandu University Medical Journal, 13(50), 125129. https://doi.org/10.3126/kumj.v13i2.1678 4

Suma'mur, P. K. (2009). Hygiene Perusahaan Dan Kesehatan Kerja (Hiperkes). In Kesehatan Kerja.

Tarwaka. (2015). Industrial Ergonomics, Knowledge Basics and Applications at Work. 2nd edition. In Ergonomi Industri. https://doi.org/10.1007/978-1-46840104-2_6

Wardhani, K. P., Rachmawati, A., Rinawati, S., \& Seviana. (2018). Faktor Faktor yang Berhubungan dengan Gejala Gangguan Sistem Pernapasan Akibat Paparan Debu Silika (SiO2) pada Area Hand Moulding I, Hand Moulding II, Hand Moulding III, Fetling dan Melting Pekerja Pabrik 1 Pengecoran PT Barata Indonesia (PERSERO). Online), 11(1), 56-66. https://doi.org/https://doi.org/10.23917/ju rnal\%20kesehatan.v11i1.7008

World Health organization. (2017). eGOHNET (Global Occupational Health Network) Newsletter. WHO. 